Original article

\title{
Tagus estuary salt marshes feedback to sea level rise over a 40-year period: Insights from the application of geochemical indices
}

\author{
B. Duarte ${ }^{\mathrm{a}, *}$, I. Caçador ${ }^{\mathrm{a}}$, J.C. Marques ${ }^{\mathrm{b}}$, I.W. Croudace ${ }^{\mathrm{c}}$ \\ a Center of Oceanography, Faculty of Sciences, University of Lisbon, Campo Grande, 1749-016 Lisbon, Portugal \\ ${ }^{\mathrm{b}}$ Institute of Marine Research - Marine and Environment Research Centre (IMAR-CMA), C/O Department of Zoology, Faculty of Sciences and Technology, \\ University of Coimbra, 3000 Coimbra, Portugal \\ ${ }^{c}$ National Oceanography Centre, Southampton, University of Southampton, European Way, Southampton SO14 3ZH, UK
}

\section{A R T I C L E I N F O}

\section{Article history:}

Received 11 April 2013

Received in revised form 17 May 2013

Accepted 17 May 2013

\section{Keywords:}

Sea level rise

Salt marshes

Geochemical indices

${ }^{137}$ Cs dating

Sediment accretion rates

Heavy metals

Elemental ratio-based indices

\begin{abstract}
A B S T R A C T
Sea level rise (SLR) has been evaluated using data acquired from two Tagus estuary salt marshes. Sediment accumulation rates over a 40 -year study period were determined using ${ }^{137} \mathrm{Cs}$ along with an evaluation of several geochemical indices and ratios as proxies of the mechisms underlying these SAR variations. Correlating SLR data from 1963 to 2001 with the sediment accretion rates (SARs) an inverse pattern of interaction was observed, with lower SAR associated to periods of higher mean sea level (MSL) heights. This pointed out to an erosion effect of the salt marsh during higher tidal flooding. Although SLR apparently slows down SAR, it still presents a positive balance with SLR, similar to that identified in most mesotidal estuaries. The geochemical analysis of sediments and chemical alteration index (CAI) also suggest that the major processes inherent to the SAR vary inversely, being mostly based by physical disturbances. Geochemical ratio-based indices showed that both salt marshes presented enhanced highenergy transport driven inputs of sediments, although in Pancas salt marsh there is a slight evidence of chemical weathering of the sediments. Anthropogenic contamination of the sediments by heavy metals was identified and has been decreasing from 1963 to 2001, mostly linked to a marked reduction of industrial activities in some areas surrounding the Tagus estuary, rather than the sedimentary history of the estuary.
\end{abstract}

(c) 2013 Elsevier Ltd. All rights reserved.

\section{Introduction}

Climate change is nowadays one major concern spanning across the environmental science community. It is widely accepted that increasing $\mathrm{CO}_{2}$ levels may induce climate change through the greenhouse effect and holds the potential to affect most ecosystems to some degree. Some direct causes of $\mathrm{CO}_{2}$ rising concentrations in the atmosphere are increasing temperature values and ocean acidification, but other may result from direct changes to the gas and particle contents within the atmosphere. The impact of an increased greenhouse effect has been widely studied (e.g. IPCC, 1990; Titus and Narayanan, 1995). The reports of the Intergovernmental Panel on Climate Change (IPCC, 1990), recently updated in 1995 , specify that the global average air and sea surface temperatures are expected to rise by about $2.5^{\circ} \mathrm{C}$, within a range of 1.5-4.5 ${ }^{\circ} \mathrm{C}$ (Berner and Berner, 1996; Houghton, 1999; IPCC, 1999), although there is a degree of uncertainty about these estimations related to issues of geographical, diurnal and seasonal variability

\footnotetext{
* Corresponding author. Tel.: +351 2175 00000x20319; fax: +351 217500009

E-mail address: baduarte@fc.ul.pt (B. Duarte).
}

(Gates, 1993; Houghton, 1999). One of the major side-effects of global warming is sea level rise, due to polar ice meltdown and increasing ocean water supply, but also caused by the thermal expansion of this larger water mass. Inevitably, the most affected areas of the globe and highly vulnerable to sea level rise are located close to the seashore, including coastal lagoons, estuaries and the shoreline. Estuaries stand out as areas of special concern, since they include some of the most densely populated areas in our planet (Duarte and Caçador, 2012; Cohen et al., 2001). Estuarine ecosystems hold therefore great scientific potential in this context and will help us understanding climate change dynamics and their impacts upon these areas.

Salt marshes are often located along estuarine sides and they are particularly vulnerable to sea level rise (Dyer et al., 2002). Salt marshes are considered to be among the most productive ecosystems on the planet and they have an essential role as nursing areas for marine fish and invertebrates of great economic value. They are invaluable habitats and feeding sites to many migratory bird species, while sheltering great biodiversity (Reed, 1990; Van Dijkeman et al., 1990). The slope of the marsh in relation to the tidal amplitude, and the elevation of the shoreline offering better protection in conditions of increasing storminess (Dyer 
et al., 2002) will be determining factors for the initial set-up and resilience of the salt marsh communities under increasing conditions of sea level rise (Simas et al., 2001). These areas are described as transitional water bodies in the Water Framework Directive of the European Union, and they are further recognized as ecologically sensible zones according to the Birds and Habitats directives. Locked between landmasses and ocean, rising seawater levels will play an important role in the future ecology of these regions. Sea level rise will also mean higher erosion rates in the outer boundary of the salt marsh (Reed, 1990). However, some mechanisms may counteract the influence of these climatic induced factors, as salt marshes also have the ability to keep their relative elevation above seawater throughout sedimentation (Salgueiro and Caçador, 2007). Salt marshes act as sinks for contaminants (Caçador et al., 2000; Duarte et al., 2010), carbon (Caçador et al., 2004) and nitrogen (Caçador et al., 2007). The major depositional process for these elements is through sedimentation of particulate matter during tidal flooding (Silva et al., 2009), when the halophytic vegetation acts as a baffle and sediment trap, leading to the settling of fine suspended particles transported on the water column that are deposited on the marsh (Silva et al., 2009). Furthermore, salt marsh growth is often associated to processes occurring in estuarine areas with high levels of sediment discharge, like mudflats (Simas et al., 2001). To counteract the effects of sea level rise, the marsh elevation must keep on at such a pace that is compatible with the rise. Otherwise flooding is inevitable and will be followed by subsequent marsh erosion. This has already been verified in the Nile and Mississippi rivers (Gornitz, 1991; Blum and Roberts, 2009). Another important factor to consider is the tidal range of the salt marsh. Stevenson et al. (1986) suggested that areas with high tidal range are associated with higher sediment transport rates, thus being less affected by sea level rise. In this case a negative feedback mechanism is observed, where a small increase in sea level leads to higher mineral deposition due to longer submersion periods. This is also associated with less sediment compaction due to reduced decomposition of organic matter in the sediment (Nyman et al., 1993; Allen, 1994). However, rapid sea levels rise, as predicted in some climate change scenarios (IPCC, 2007) increases salt-marsh loss caused by the increased submersion periods since salt marsh productivity (organogenic input) is suppressed (Nyman et al., 1993, 1994). Recently, an increasing number of numerical modelling studies have appeared aimed at identifying and simulate the main processes of marsh elevation dynamics in response to changing sea level (Allen, 1990, 1995, 1997; Callaway et al., 1996; Chmura et al., 1992; Day et al., 1999; French, 1993; Krone, 1987; Morris et al., 2002; Pont et al., 2002; Rybczyk and Cahoon, 2002; Rybczyk et al., 1998; Temmerman et al., 2003a; Van Wijnen and Bakker, 2001). However, as stated by Allen (2000), these models are at a rather embryonic stage of development. Important information can be obtained meanwhile from empirical studies of saltmarsh systems. By investigating sedimentary records in the context of the climate conditions that produced them it should be possible to understand how salt marsh geochemical characteristics and accretion rates have been responding to changes in sea level. This type of information will be very useful in practice, allowing for better adaptive management of human activities, and hopefully to guide our preparation and protective measures against future scenarios.

Caesium-dating techniques are widely applied to SLR and SAR studies in coastal environments. Although its undeniable efficiency providing good insights on SAR, they only tell half the story. This way, the present work not only aims to assess sediment accumulation rates in the Tagus salt marsh over the last 40 years using ${ }^{137}$ Cs dating, but also the possible application of geochemical and elemental-based indices in order to provide insights on the processes behind the temporal oscillations and spatial variations in the SAR. In a time of major concern in which respects to global changes,

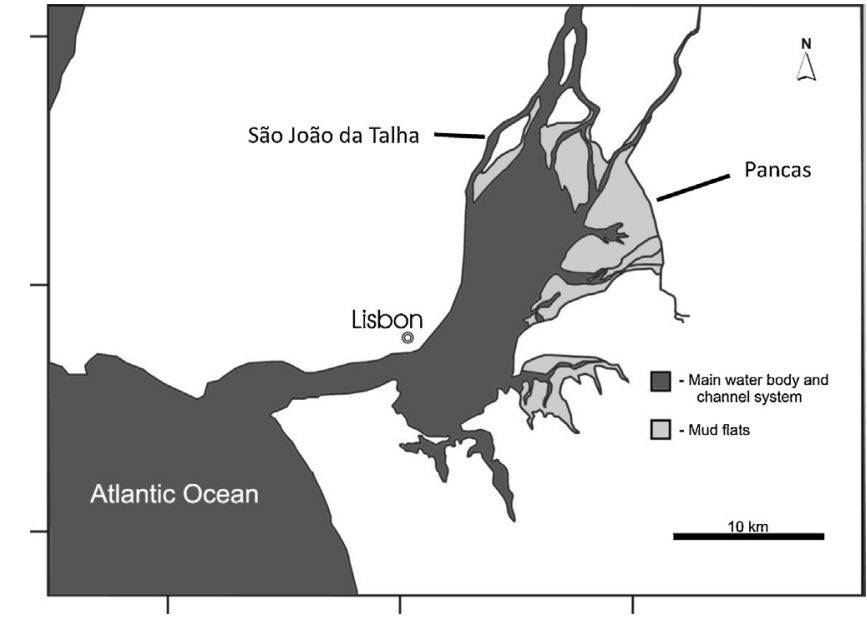

Fig. 1. Map of the Tagus estuary showing Pancas and S. João da Talha salt marsh sampling stations.

this analysis will be integrated in the context of rising sea level conditions. This way is intended not only to evaluate the possible use of this geochemical indices but also to use them as storytellers of the recent past of Tagus estuary.

\section{Material and methods}

\subsection{Study area description}

The Tagus estuary is the largest estuary on the west coast of Europe ( $38^{\circ} 44^{\prime} \mathrm{N}, 9^{\circ} 08^{\prime} \mathrm{W}$ ), located in the most populated area of Portugal (Fig. 1). It is a shallow estuary and its circulation is mainly driven by tides. The Tagus River drains a total area of $86,629 \mathrm{~km}^{2}$, representing the second most important hydrological basin in the Iberian Peninsula. The river is the main source of freshwater into the estuary. Inflow fluctuates seasonally with an average monthly value varying from $120 \mathrm{~m}^{-3} \mathrm{~s}^{-1}$ in summer to $653 \mathrm{~m}^{-3} \mathrm{~s}^{-1}$ in winter (last 30 years of Water National Institute public database, INAG). Estimated water residence time ranges from 6 to $<65$ days for winter and summer average river discharge, respectively (Martins et al., 1984). It is a mesotidal estuary according to the NOAA classification, with semi-diurnal tides ranging from $0.4 \mathrm{~m}$ at neap tide to $4.1 \mathrm{~m}$ at spring tide. Seawater enters the estuary through a deep narrow inlet channel. The tidal influence reaches $80 \mathrm{~km}$ inland from Lisbon.

Coring took place at Pancas (PAN) salt marsh, located in the southern side of the Tagus estuary within the Natural Reserve of Tagus Estuary and in S. João da Talha (SJT) salt marsh, located in the northern side in Lisbon metropolitan zone. Three sediment cores were taken using a tubular probe $(6.7 \mathrm{~cm}$ diameter $)$ in 2001 . The cores were taken along the salt marsh in an area vegetated by Sarcocornia perennis. Appropriate measures were taken to avoid compaction during the coring. The position of the cores and vertical level of the coring sites was attained by GPS.

\subsection{Laboratory analysis}

The cores obtained at the sampling stations were brought back to the laboratory in refrigerated chambers and sliced. The samples were dried to constant weight at $60^{\circ} \mathrm{C}$. Organic matter content was determined by loss on ignition (LOI) after slowly ashing subsamples at $600^{\circ} \mathrm{C}$ for $3 \mathrm{~h}$.

The sediment accumulation rate was calculated on the basis of the two pronounced ${ }^{137}$ Cs-peaks, which were present in all the cores. The lower peak corresponds to the 1963 maximum in testing of nuclear weapons in the atmosphere and the upper peak is 
due to the accident at the nuclear power plant at Chernobyl in 1986. These two peaks have been used as markers and the average accumulation rate during the period 1963-1986 has been calculated as the accumulated mass between the two peaks divided by the time between the two events ( 23 years). The accumulation from 1986 to the time of coring (2003-2005) has been calculated in a similar way. The organic content in the cores decreases with depth and consists primarily of roots and macrofragments of the salt marsh vegetation. Inclusion of this organic material in the calculations of accumulation rates would induce systematic errors, as the density of roots and plant fragments is higher in top of salt marsh sediments. The subject of the present study is the primarily minerogenic allocthonous sediment and calculated masses were therefore corrected for organic content. The minerogenic fraction of the sediment was calculated by reducing the total dry weight with the LOI percentage. Samples were analyzed for ${ }^{137} \mathrm{Cs}$ activity, using gamma-spectrometry by way of its peak at $661 \mathrm{keV}$. Depth of the 1963 peak (Ritchie and McHenry, 1990a,b) was used to investigate the accumulation rates, while the sediment accumulation rates (SAR) were computed taking into account the diameter of the corer and an average sediment density of $1020 \mathrm{~kg} \mathrm{~m}^{-3}$, obtained for the Tagus salt marshes in previous studies (Salgueiro and Caçador, 2007). Sedimentation values were also corrected for organic matter content, considering the organic percentage found in the different layers. These values were taken in account to eliminate for any possible artefacts caused by the fact that each layer in our sample is at a different stage of organic decomposition.

Geochemical analysis of the sediments and their heavy metal content was carried out through X-ray fluorescence spectrometry (XRF). The sediments were frozen-dried and compressed into tablets. XRF was performed in a Philips Magix-Pro WD-XRF unit at the National Oceanography Center (NOC) in Southampton, UK. After knowing the relevant data from the oxides composition it was possible to work out the Chemical Alteration Index (CAI):

$\mathrm{CAI}=\frac{\mathrm{Al}_{2} \mathrm{O}_{3}}{\mathrm{Al}_{2} \mathrm{O}_{3}+\mathrm{CaO}+\mathrm{K}_{2} \mathrm{O}+\mathrm{Na}_{2} \mathrm{O}}$

This index provides information about the type of disturbance affecting the sediments. In practice, CAI values below 40 suggest the absence of disturbance, and values from 40 to 70 are typical of physical disturbance only, while index values above 70 essentially are indicators of chemical disturbance of the sediments (Cox and Lowe, 1995).

\subsection{Sea level data}

The tidal gauge closest to both studied salt marshes is the Cascais tidal gauge (www.igeo.pt) located in the same tidal basin at the mouth of the estuary. This gauge holds recordings from 1880 to present. Tidal heights for the period comprehended from 1880 to the time of coring (2001), were obtained from the Hydrographic Institute (www.hidrografico.pt) and their dataset for the Lisbon station. The annual heights were plotted and a linear regression was made, in order to establish a sea level rise rate (Andersen et al., 2011).

\section{Results}

\section{1. ${ }^{137}$ Cs dating and sediment accumulation rates}

The isotopic analysis of the cores showed two major peaks of ${ }^{137}$ Cs consistent with the recent history of NW Europe. The lower peak corresponds to the input of bomb test material that had its higher activity period in 1963 . The upper peak is normally identified as ${ }^{137}$ Cs deposition resulting from the Chernobyl accident in 1986 (Andersen et al., 2000). These peaks were chosen as markers for
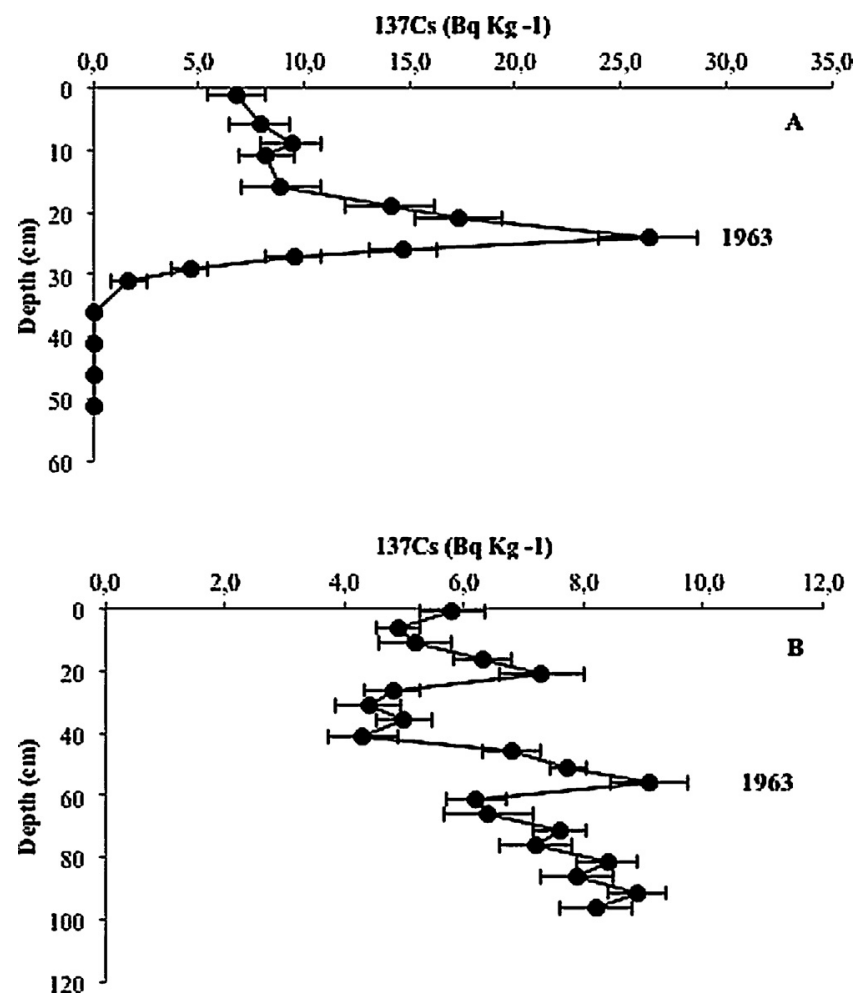

Fig. 2. Vertical profiles of ${ }^{137} \mathrm{Cs}$ activity in salt marsh soil obtained from core samples collected at Pancas (A) and S. João da Talha (B).

those events and allowed us to consider two different time periods for the purpose of this study: from 2001 to 1986 and from 1986 to 1963 (Fig. 2).

Using these radiometric markers the average SAR were assessed for both time periods (Table 1) and this allows for increased accuracy in our analysis and better discrimination of the sedimentation history at the two saltmarsh stations for the study years (1963-2001). The radiometric vertical profile in our cores shows rather obvious peaks of higher ${ }^{137} \mathrm{Cs}$ activity at different depths and these peaks have been observed for the two salt marshes. However, while the 1986 peak was detected at a depth of $9 \mathrm{~cm}$ in the Pancas (PAN) salt marsh, the same peak has been detected further down in SJT, occurring at a depth of $21 \mathrm{~cm}$. A similar pattern was found also for the 1963 peak, occurring at a depth of $24 \mathrm{~cm}$ in Pancas and $56 \mathrm{~cm}$ deep in SJT. The SAR values have been assessed from this type of radiometric dating (Table 1) and for the years 1963-2001 the accretion was always higher in the SJT station when compared to PAN. There was an altitudinal increase of $0.10 \mathrm{~cm}$ associated to the accretion rates for the 1963-1986 and 1986-2001 time intervals

Table 1

Calculated total and mineral sedimentation $\left(\mathrm{kg} \mathrm{m}^{-2} \mathrm{y}^{-1}\right)$ and accretion $\left(\mathrm{cm} \mathrm{y}^{-1}\right)$ rates based on ${ }^{137} \mathrm{Cs}$ peaks in both salt marshes.

\begin{tabular}{lcc}
\hline & Pancas (PAN) & S. João Talha (SJT) \\
\hline $\begin{array}{lc}\text { Apparent sediment accumulation rate } \\
1963-1986\end{array}$ & \\
$1986-2001$ & $5.44 \pm 0.33$ & $15.52 \pm 0.78$ \\
$1963-2001$ & $6.17 \pm 0.31$ & $13.60 \pm 0.68$ \\
Real sedimentation rate & & $14.76 \pm 0.74$ \\
$1963-1986$ & $6.03 \pm 0.30$ & \\
$1986-2001$ & $4.87 \pm 0.24$ & $13.17 \pm 0.66$ \\
$1963-2001$ & $5.60 \pm 0.28$ & $11.06 \pm 0.55$ \\
Accretion rate & & $12.25 \pm 0.61$ \\
$1963-1986$ & $0.65 \pm 0.04$ & \\
$1986-2001$ & $0.53 \pm 0.00$ & $1.52 \pm 0.00$ \\
$1963-2001$ & $0.61 \pm 0.03$ & $1.33 \pm 0.01$ \\
\hline
\end{tabular}


Table 2

Geochemical characterization of the sediment cores of SJT and PAN sites at the depths dated as 1963, 1986 and 2001 (average \pm standard deviation).

\begin{tabular}{|c|c|c|c|c|c|c|}
\hline & \multicolumn{3}{|l|}{ SJT site } & \multicolumn{3}{|l|}{ PAN site } \\
\hline & 1963 & 1986 & 2001 & 1963 & 1986 & 2001 \\
\hline $\mathrm{SiO}_{2}$ & $54.5 \pm 0.3$ & $54.0 \pm 0.4$ & $45.3 \pm 8.7$ & $58.7 \pm 0.7$ & $57.4 \pm 0.7$ & $51.8 \pm 4.1$ \\
\hline $\mathrm{Al}_{2} \mathrm{O}_{3}$ & $19.4 \pm 0.4$ & $19.1 \pm 0.3$ & $16.8 \pm 2.7$ & $20.7 \pm 0.5$ & $20.7 \pm 0.6$ & $17.8 \pm 1.8$ \\
\hline $\mathrm{TiO}_{2}$ & $0.9 \pm 0.1$ & $0.9 \pm 0.1$ & $0.8 \pm 0.1$ & $0.9 \pm 0.0$ & $0.9 \pm 0.0$ & $0.7 \pm 0.1$ \\
\hline $\mathrm{Fe}_{2} \mathrm{O}_{3}$ & $7.8 \pm 0.6$ & $7.9 \pm 0.5$ & $6.6 \pm 0.5$ & $7.0 \pm 0.5$ & $7.7 \pm 0.0$ & $6.9 \pm 0.6$ \\
\hline $\mathrm{MnO}$ & $0.1 \pm 0.0$ & $0.1 \pm 0$ & $0.1 \pm 0.0$ & $0.1 \pm 0.0$ & $0.1 \pm 0.0$ & $0.1 \pm 0.0$ \\
\hline $\mathrm{MgO}$ & $3.1 \pm 0.1$ & $3.0 \pm 0.1$ & $2.9 \pm 0.1$ & $3.1 \pm 0.2$ & $3.1 \pm 0.4$ & $3.1 \pm 0.2$ \\
\hline $\mathrm{CaO}$ & $4.2 \pm 0.2$ & $4.4 \pm 0.3$ & $4.0 \pm 0.4$ & $1.1 \pm 0.3$ & $0.9 \pm 0.5$ & $1.0 \pm 0.5$ \\
\hline $\mathrm{K}_{2} \mathrm{O}$ & $3.8 \pm 0.3$ & $3.6 \pm 0.2$ & $3.3 \pm 0.2$ & $3.7 \pm 0.1$ & $3.7 \pm 0.1$ & $3.3 \pm 0.3$ \\
\hline $\mathrm{Na}_{2} \mathrm{O}$ & $2.2 \pm 0.2$ & $1.6 \pm 0.4$ & $1.7 \pm 0.5$ & $1.8 \pm 0.2$ & $1.7 \pm 0.3$ & $4.8 \pm 2.5$ \\
\hline $\mathrm{P}_{2} \mathrm{O}_{5}$ & $0.2 \pm 0.0$ & $0.3 \pm 0.0$ & $0.3 \pm 0.0$ & $0.2 \pm 0.0$ & $0.3 \pm 0.1$ & $0.3 \pm 0.1$ \\
\hline Sum & $96.2 \pm 1.1$ & $95.1 \pm 0.3$ & $81.7 \pm 13.2$ & $97.2 \pm 0.8$ & $96.5 \pm 1.4$ & $89.8 \pm 4.1$ \\
\hline CAI & $65.4 \pm 1.2$ & $66.5 \pm 0.7$ & $64.9 \pm 0.8$ & $75.9 \pm 0.9$ & $76.5 \pm 0.8$ & $66.2 \pm 6.7$ \\
\hline $\mathrm{Al}_{2} \mathrm{O}_{3} / \mathrm{SiO}_{2}$ & $2.8 \pm 0.1$ & $2.8 \pm 0.1$ & $2.7 \pm 0.1$ & $2.8 \pm 0.1$ & $2.8 \pm 0.1$ & $2.9 \pm 01$ \\
\hline
\end{tabular}

observed in Pancas salt marsh, and this compares to some $0.20 \mathrm{~cm}$ in the SJT station for the same period. This difference becomes more evident when comparing data in terms of mass deposition by square metre of salt marsh soil area, or total sedimentation rate. Differences among our stations were in the order of $10 \mathrm{~kg}$ of sediment deposited on a square metre of salt marsh, further emphasizing the elevated accretion rates observed in the SJT site. Whenever the cores did exhibit different organic matter values due to variations in decomposition rates within the vertical profile, these values of total sedimentation were corrected for its organic matter (as loss on ignition) and expressed as mineral sedimentation rate.

\subsection{Sea level rise data}

The local variation of mean sea level (MSL) for the evaluated periods is plotted in Fig. 3. Plotting a linear trend for the whole study period (1880-2001) a rate of increase of the MSL was assessed at about $1.29 \mathrm{~mm} \mathrm{y}^{-1}$ in this area. The yearly mean values did oscillate around $10.5 \mathrm{~mm}$ during the study period. The mean water depth in those areas where the lowest part of both salt marshes will be covered by the incoming tide stays about $1 \mathrm{~m}$ above the national chart datum - Portuguese Hydrographic Zero (PHZ). This MSL rise will have major consequences in the ecology of the salt marsh, associated to longer inundation periods during the high tide periods.

\subsection{Elemental analysis}

The geochemical analysis of the sediments (Table 2) revealed that the $\mathrm{SiO}_{2}$ content has been decreasing from 1963 to 2001,

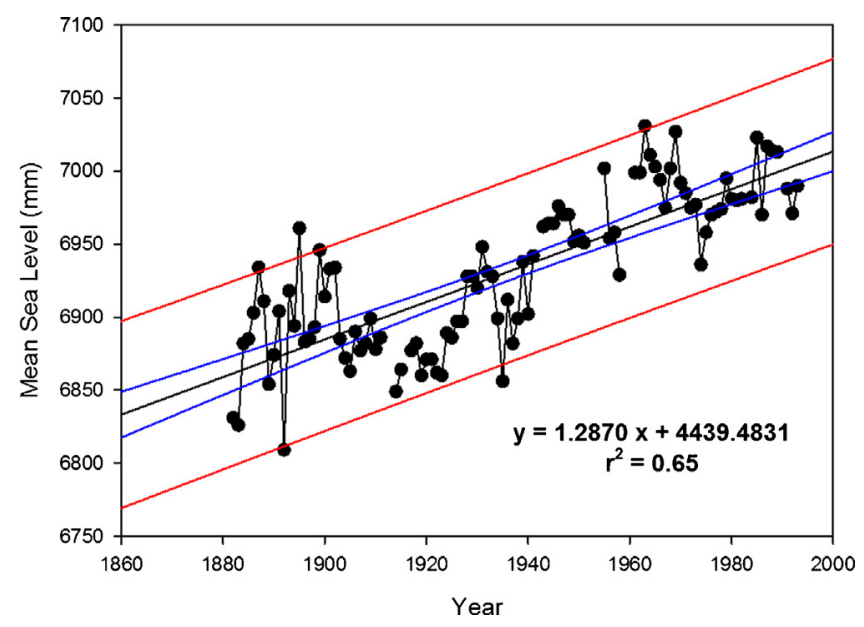

Fig. 3. Changes in Mean Sea Level values (mm) monitored from 1963 to 2001. remaining higher in cores from PAN when compared to SJT. Major differences were also observed for $\mathrm{CaO}$ in the two salt marshes. In both cases the values for $\mathrm{CaO}$ throughout the chronosequence did remain rather stable during the period of our analysis, but SJT showed higher values of $\mathrm{CaO}$ when compared to PAN.

As for $\mathrm{Na}_{2} \mathrm{O}$, there was a decrease of this oxide from 1963 to 2001 at SJT, while in PAN there was an evident increase from 1986 to 2001. This difference in oxide composition at the two sites is evident also when we look into the CAI values. In both salt marshes there was an increase of the CAI values from 1963 to 1986, and a subsequent decrease from 1986 to 2001. In this case, the decrease was more evident in Pancas salt marsh. The values observed for both oxides in the two salt marshes are consistent with current interpretation of predominant physical disturbance mechanisms influencing the geochemistry of the sediments (Cox and Lowe, 1995), and this is more evident in Pancas (PAN).

The ratios $\mathrm{Si} / \mathrm{Al}$ and $\mathrm{Si} / \mathrm{K}$ are dependent upon the proportion of the coarse materials, mainly formed by quartzitic sands containing high percentages of silicon, and fine clays which contain $\mathrm{Si}, \mathrm{Al}$ and K. Comparing these ratios (Fig. 4), it is possible to observe a strong relationship between the two ratios in Pancas salt marsh, while in SJT the Si/K ratio remains rather stable despite variations in the $\mathrm{Si} / \mathrm{Al}$ ratio.

Iron and phosphorous are rather abundant elements with high importance on sediment biogeochemistry. A variation on $\mathrm{P} / \mathrm{Ca}$ and $\mathrm{P} / \mathrm{Fe}$ ratios indicates an accumulation of organic phosphorus and influences the mechanisms controlling the amount of total phosphorus in sediments. Although the more obvious pattern was found again in the Pancas salt marsh sediments (with a strong correlation between the two ratios), there is also evidence of a correlation between Fe and P (Al normalized values) for the SJT salt marsh, although with smaller variability than found at Pancas.

Calcium and magnesium are the most abundant alkaline-earth elements in reservoir sediments, with Ca mainly present as carbonate minerals in this kind of sediments. Similar to the Si/Al and $\mathrm{Si} / \mathrm{K}$ ratios, analysis of the variation of these elements (Fig. 4) shows also

Table 3

Elemental standard shale concentrations (Turekian and Wedepohl, 1961) in the earth continental crust ( $\mathrm{ppm}$ ) and average concentration in both studied salt marshes (average \pm standard deviation).

\begin{tabular}{llcc}
\hline & Standard shale* & SJT & Pancas \\
\hline $\mathrm{As}$ & 13 & $50.7 \pm 10.1$ & $34.5 \pm 11.3$ \\
$\mathrm{Co}$ & 24 & $18.1 \pm 2.2$ & $13.0 \pm 1.5$ \\
$\mathrm{Cr}$ & 90 & $110.8 \pm 12.9$ & $100.5 \pm 8.2$ \\
$\mathrm{Cu}$ & 45 & $74.3 \pm 15.7$ & $54.7 \pm 5.4$ \\
$\mathrm{Ni}$ & 68 & $39.1 \pm 9.2$ & $31.3 \pm 3.0$ \\
$\mathrm{~Pb}$ & 20 & $160.2 \pm 48.7$ & $93.4 \pm 23.5$ \\
$\mathrm{Zn}$ & 95 & $553.9 \pm 99.6$ & $347.0 \pm 92.4$ \\
\hline
\end{tabular}


São João da Talha (SJT)

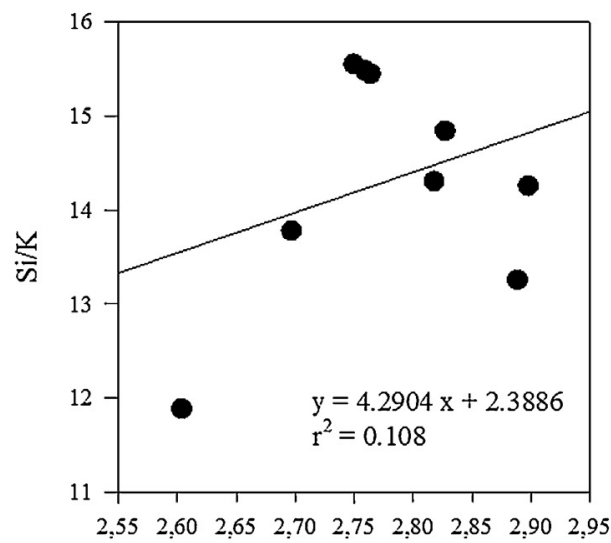

$\mathrm{Si} / \mathrm{Al}$
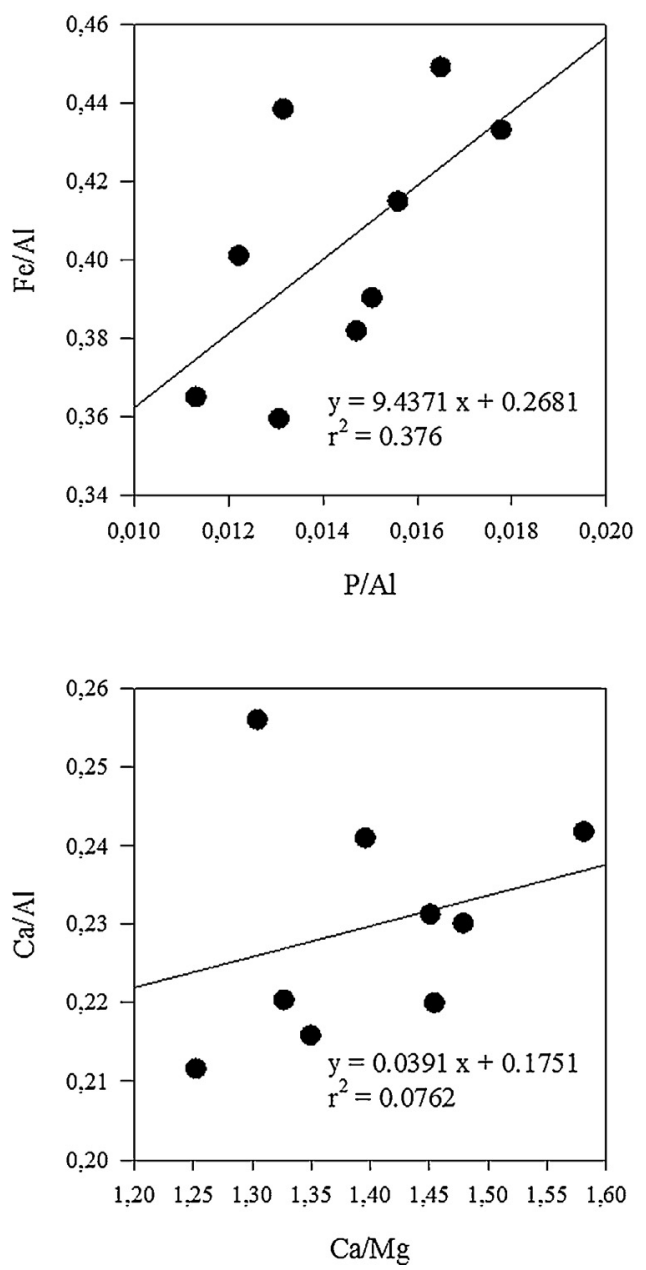

Pancas (PAN)
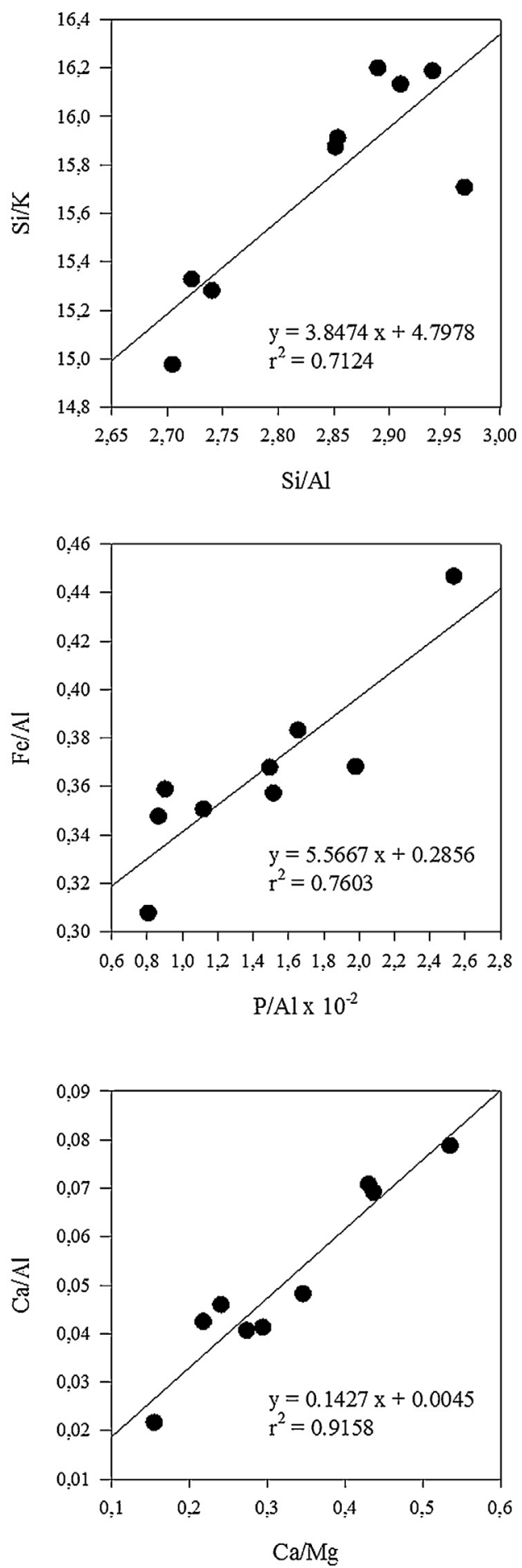

Fig. 4. Geochemical ratios obtained from ${ }^{137}$ Cs-dated sediments collected at the two salt marsh sampling stations monitored on the Tagus estuary.

a strong and obvious correlation in the sediments from Pancas salt marsh, while in the SJT salt marsh this relationship was not found.

The heavy metal content in the layers dated by ${ }^{137} \mathrm{Cs}$ (Fig. 5) did show similar spatial and temporal trends for all metals. The metal concentrations in SJT samples were always higher than in samples from PAN, except for $\mathrm{Ni}$ and $\mathrm{Cr}$ in 2001 when both stations had very similar values. It was also possible to observe a temporal trend for all the metals included in our analysis, with concentrations in the sediments decreasing from 1963 to 2001. Comparing the average values determined for both salt marshes included in this study with those provided by Turekian and Wedepohl (1961) for the 'standard shale' (Table 3) may give some indication about the importance of anthropogenic components relative to typical geogenic (nonpolluted) components. Lead and $\mathrm{Zn}$ are present on the Tagus estuary and they occur at approximately 5 times their typical geogenic concentrations, particularly in the sediments collected 

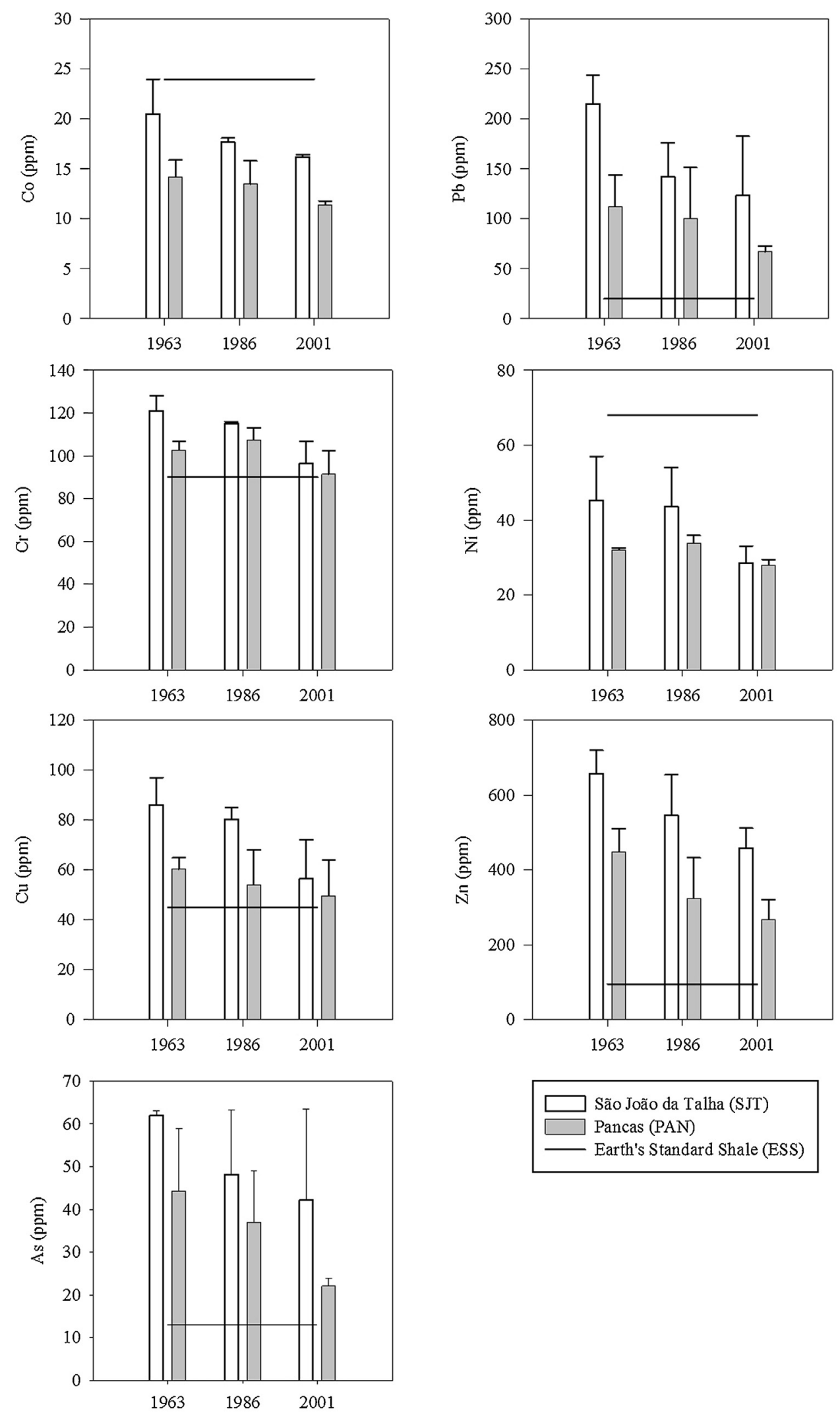

São João da Talha (SJT) Pancas (PAN)

Earth's Standard Shale (ESS)

Fig. 5. Heavy metal concentrations measured in ${ }^{137} \mathrm{Cs}$-dated sediments collected at the São João da Talha (SJT) and Pancas (PAN) salt marsh sampling stations.

in the SJT salt marsh. This indicates anthropogenic introduction of these heavy metals in the Tagus estuarine system, particularly in the northern part of the estuary near the Lisbon metropolitan area.

\section{Discussion}

The well-defined ${ }^{137}$ Cs-peaks observed in the dated sediments, consistent with the two periods of major releases of Cs into the 
environment, strongly indicates that Cs is immobile in the studied salt marshes, mainly formed by minerogenic sediment. Previous studies (DeLaune et al., 1978; Croudace and Cundy, 1995) made using the 1963-peak in salt marsh sediments support these findings and showed that $C$ s is virtually non-exchangeable in this kind of fine estuarine sediments.

Sea level rise may have two major influences in salt marshes accretion rates. With higher MSL heights the tidal inundation frequency of a marsh tends to increase, leading to higher suspended sediment supply to the marsh via settling particles. Also, there is an effect of higher erosion rates due to changes in the semidiurnal tidal flooding and drawback of the tidal waters (Roman et al., 1997). Evaluating tidal gauge MSL heights and the SAR both mechanisms can be identified. From 1963 to 1986 there was a higher sedimentation and accretion rates in both salt marshes. In contrast, from 1986 to 2001 there was a decrease in the sedimentation and accretion rates also in both marshes. Both events point out to the same mechanism of marsh morphodynamics. During periods of high MSL the main effect of tidal inundation is erosion of the marsh. Despite all evidences concomitant with this kind of morphodynamic mechanism, some additional factors must also be considered, like storm frequency (Roman et al., 1997; Dyer et al., 2002), elevation in the tidal frame, tidal channel migration (Reed, 1990; Ward et al., 1998), exposure to wave attack (Oenema and DeLaune, 1988) and anthropogenic influences such as land reclamation (Sarreta et al., 2010).

Although subsurface sediment compaction could not be estimated in the study area, it seems unlikely to be a significant process contributing to changes in marsh elevation, at least over the time scale here investigated (Goodman et al., 2007). Although SLR apparently slows down the accretion rates in the Tagus salt marshes, there is still a positive balance with sea-level rise. This agrees well with other studies about sedimentation in mesotidal marshes (Wood et al., 1989), which normally exhibit an obvious relation between sea-level rise and accretion rates, in opposition to macrotidal estuaries (Détriché et al., 2011).

In contrast, in macrotidal marshes there is not such an evident relationship (Goodman et al., 2007). The fact that most marshes do show a significant build-up of vertical accretion, that exceeds the MSL, is in part attributed to the spatial variation in SAR being influenced by the topography of the estuary itself and consequently influencing the frequency and duration of tidal flooding at each marsh (French, 2006). Theoretically, it could be expected that as the marsh builds up due to vertical accretion, this process would slow down enabling that the upper marsh achieves an elevation close to the equilibrium state between the rates of sedimentation and sea level rise. However, this cannot be observed over the small time scale considered here but might be if centennial or millennial scales were investigated (French and Burningham, 2003; French, 2006). Allen (1999) also suggests that another key factor influencing the present SAR is the auto-compaction of the Holocene coastal sequences. This will have an important impact in the marsh topographies, enhancing short-term sedimentations. Further insights about the history of the sediments and other phenomena underlying a temporal sequence of sedimentation rates, is the geochemical data concerning the sediment oxides composition. Cox and Lowe (1995) provided an index of chemical alteration (CAI) as a tool for evaluating the nature of sediment disturbance, physical or chemical. Our data further suggests that the major processes inherent to the variations of the sedimentation rates that change inversely to the MSL variation are of physical nature, like the erosion/deposition mechanisms. Using CAI values obtained from the sediment it is also possible to validate this hypothesis, which is more obvious for the SJT sites. All CAI values with a time scale associated that are available from this saltmarsh indicate physical disturbance of the sediment (CAI values falling between 40 and 70 ), whilst at the PAN sites only sediments from
2001 had values of CAI consistent with physical disturbance. In sediments that have been assigned to years from 1963 to 1986, the CAI values are slightly above 70 , indicating some sort of chemical disturbance to the composition of the sediments. The most obvious modification to the composition of sediments was the comparatively high increase of $\mathrm{Na}_{2} \mathrm{O}$ incorporated from 1986 to 2003, probably due to the higher flooding frequencies associated to higher MSL. This may be due to a mineral effect of these conditions or to the incorporation of larger amounts of Na coming from longer periods of inundation of the sediments with Na-rich seawater.

Both salt marshes show increases in $\mathrm{Si} / \mathrm{Al}$ and $\mathrm{Si} / \mathrm{K}$ and possibly these are related to an enhanced input of quartz, which in turn may be due to eolian inputs (Werne et al., 2002), but also to higher energy transport. Pancas sediments show signs of weathering, presenting lower values of Si/Al. Therefore, $\mathrm{Si} / \mathrm{Al}$ ratios in Pancas salt marsh seem related to chemical weathering rather than hydrodynamics (Lopez et al., 2006), as suggested also by the CAI values.

$\mathrm{Ca} / \mathrm{Mg}$ ratios in both salt marshes increased with $\mathrm{Ca} / \mathrm{Al}$, suggesting that magnesium is mainly associated to the aluminosilicate fraction. The relative abundance of sedimentary calcium, expressed by the $\mathrm{Ca} / \mathrm{Al}$ ratio, especially in the STJ salt marsh sediments, is clearly related to water mineralization, as expected from the high solubility of calcite (Tardy et al., 2004).

The clearest relationship of sedimentary phosphorus with other sedimentary elements appears between iron and phosphorus when concentrations are normalized relative to the aluminium content (i.e. when $\mathrm{P} / \mathrm{Al}$ and $\mathrm{Fe} / \mathrm{Al}$ ratios are used instead of rough concentrations). This relationship does not reflect dominance of any particular sedimentary phosphorus fraction. What it really reflects is that the increase of phosphate concentration over the background composition (which in turn may be dominated by calcium, iron or organic phosphorus) is linked with the increase in iron across the same background material. It is well known that authigenic iron oxi-hydroxides have a high capacity to adsorb phosphorus onto their surface (Lijklema, 1980; López et al., 1996). Thus, precipitation and accumulation of authigenic iron-oxides causes a corresponding increase in $\mathrm{P} / \mathrm{Al}$ and $\mathrm{Fe} / \mathrm{Al}$ and seems to be the main process explaining the global variability observed in Spanish reservoirs (López et al., 1996). Nevertheless, the high variability in the $\mathrm{P} / \mathrm{Fe}$ ratio observed in the eastern reservoirs also indicates that other processes must be accounted for in order to explain the variability of sedimentary phosphorus within calcareous areas.

Overlooking the potential risk of heavy metals settling associated to higher MSL seems to have the opposite behaviour. Although the fluctuations of MSL, the overall trend shows a marked increase as observed in almost all over the globe, the pattern of contamination by heavy metals in the dated layers does not follow the same pattern. From 1963 to 2001 there is a clear decrease of the heavy metal content in the sediments. This may be associated to the recent history of industries in the area. In fact, the peak of waste dumping and heavy metal introduction in the estuary has occurred in 1970-1980 (Caçador et al., 2000), when the heavy industry dominated most of the southern parts of the estuary. Following the introduction of strict environmental policies a large number of industries were deactivated since that period and the remaining ones are now subjected to severe measures of contaminant control. This led to a decrease in the incorporation of heavy metals over recent years and is also consistent with values observed in the Pancas salt marsh, which are always lower than in the SJT salt marsh. Pancas is located in the upper eastern part of the estuary and within the Tagus Natural Reserve area, well away from the major centres of industry, while SJT is more subject to anthropogenic pressures due to its location closer to Lisbon and into an area that was highly industrialized until 1990. Apparently the consecutive newer layers of sediments deposited at increasing MSL, are cleaner than the ancient ones, being related to the industrial history of the estuary. 
Thus, and although the lower values of sedimentation registered during the higher industrial activity decades, sediment contamination is not affected by the amount of sediment deposited in the marsh but by its contamination, pointing once again to the underlying industrial evolution of the Tagus estuary.

\section{Conclusions}

MSL in the Tagus estuary follows a trend already identified in other estuaries around the globe (Blum and Roberts, 2009; Rybczyk et al., 1998), with increasing sea heights and higher inundation frequencies. Caesium-based dating of the sediments showed that SAR in the Tagus salt marshes presents decrease in the amount of sediments deposited as the MSL increases. Although the decreasing rate of marsh elevation, during the study period (1963-2001), there was still a positive feedback to MSL rise increase. Considering an approximate rate of SLR similar to that observed in 1963-2001, Tagus salt marshes (although with slower SAR) may still be able to adjust to SLR and therefore will contribute to protect the nearby shoreline from higher inundation. Coupling this data with the provided from the geochemical and elemental-based indices, the mechanisms underlying this decrease could be unveiled. The elemental ratios showed that the marshes elevation was mostly affected by physical disturbances and chemical weathering. Heavy metal tracers in dated sediment layers, although it is not related to sedimentary events or disturbance, proved also to provide good insights on the changes in industrial history of the Tagus estuary. The inclusion of geochemical and element-based indices into SLR studies appears, this way, as an efficient tool, acting as storytellers of the sediment history providing valuable insights on the mechanisms underlying salt marshes feedbacks to SLR.

\section{Acknowledgments}

The authors would like to thank to the "Fundação para a Ciência e Tecnologia (FCT)" for funding the research in the Centre of Oceanography (CO) throughout the project PEst-OE/MAR/UI0199/2011, the Institute of Marine Research (IMAR) throughout the project PEst-C/MAR/UI0284/2011 and this specific work throughout the ECOSAM project (PTDC/AAC-CLI/104085/2008). B. Duarte investigation was supported by FCT throughout a PhD grant (SFRH/BD/75951/2011).

\section{References}

Allen, J.R.L., 1990. Salt-marsh growth and stratification: a numerical model with special reference to the Severn Estuary, southwest Britain. Mar. Geol. 95, 77-96.

Allen, J.R.L., 1994. A continuity-based sedimentological model for temperate-zone tidal salt marshes. J. Geol. Soc. 151, 41-49.

Allen, J.R.L., 1995. Salt-marsh growth and fluctuating sea level: implications of a simulation model for Flandrian coastal stratigraphy and peat-based sea-level curves. Sediment. Geol. 100, 21-45.

Allen, J.R.L., 1997. Simulation models of salt-marsh morphodynamics: some implications for high-intertidal sediment couplets related to sea-level change. Sediment. Geol. 113, 211-223.

Allen, J.R.L., 1999. Geological impacts on coastal wetland landscapes: some general effects of sediment autocompaction in the Holocene of northwest Europe. Holocene 9, 1-12.

Allen, J.R.L., 2000. Morphodynamics of Holocene salt marshes: a review sketch from the Atlantic and Southern North Sea coasts of Europe. Quat. Sci. Rev. 19, 1155-1231.

Andersen, T.J., Mikkelsen, O.A., Møller, A.L., Pejrup, M., 2000. Deposition and mixing depths on some European intertidal mudflats based on $210 \mathrm{~Pb}$ and $137 \mathrm{Cs}$ activities. Continental Shelf Res. 20,1569-1591.

Andersen, T.J., Svinth, S., Pejrup, M., 2011. Temporal variation of accumulation rates on a natural salt marsh in the 20th century - the impact of sea level rise and increased inundation frequency. Mar. Geol. 279, 1-4.

Berner, E.K., Berner, R.A., 1996. Global Environment: Water, Air and Geochemical Cycles. Prentice-Hall, USA.

Blum, M., Roberts, H., 2009. Drowning of the Mississippi Delta due to insufficient sediment supply and global sea-level rise. Nat. Geosci. 2, 488-491.
Caçador, I., Costa, A.I., Vale, C., 2007. Nitrogen sequestration capacity of two salt marshes from the Tagus estuary. Hydrobiologia 587, 137-145.

Caçador, I., Costa, A.I., Vale, C., 2004. Carbon storage in Tagus saltmarsh sediments. Water Air Soil Pollut Focus 4, 701-714.

Caçador, I., Vale, C., Catarino, F., 2000. Seasonal variation of $\mathrm{Zn}, \mathrm{Pb}, \mathrm{Cu}$ and $\mathrm{Cd}$ concentrations in the root-sediment system of Spartina maritima and Hallimione portulacoides from Tagus estuary salt marshes. Mar. Environ. Res. 49, 279-290.

Callaway, J.C., DeLaune, R.D., Patrick Jr., W.H., 1996. Chernobyl 137Cs used to determine sediment accretion rates at selected northern European coastal wetlands. Limnol. Oceanogr. 4, 444-450.

Chmura, G.L., Costanza, R., Kosters, E.C., 1992. Modelling coastal marsh stability in response to sea level rise: a case study in coastal Louisiana, USA. Ecol. Model. 64, 47-64.

Cohen, T., Hee, S., Ambrose, R., 2001. Trace metals in fish and invertebrates of three California Coastal Wetlands. Mar. Pollut. Bull. 42, 232-242.

Cox, R., Lowe, D.R., 1995. A conceptual review of regional-scale controls on the composition of clastic sediment and the co-evolution of continental blocks and their sedimentary cover. J. Sediment. Res. 65, 1-12.

Croudace, I.W., Cundy, A.B., 1995. Heavy metal and hydro-carbon pollution in recent sediments from Southampton ater, southern England: a geochemical and isotopic study. Environ. Sci. Technol. 29, 1288-1296.

Day, J.W., Rybczyk, J., Scarton, F., Rismondo, A., Are, D., Cecconi, G., 1999. Soil accretionary dynamics, sea-level rise and the survival of wetlands in Venice Lagoon: a field and modelling approach. Estuarine Coastal Shelf Sci. 49, 607-628.

DeLaune, R.D., Patrick Jr., W.H., Buresh, R.J., 1978. Sedimentation rates determined by 137 Cs dating in a rapidly accretion salt marsh. Nature $275,532-533$.

Détriché, S., Susperregui, A.-S., Feunteun, E., Lefeuvre, J.-C., Jigorel, A., 2011. Interannual (1999-2005) morphodynamic evolution of macro-tidal salt marshes in Mont-Saint-Michel Bay (France). Continental Shelf Res. 31, 611-630.

Duarte, B., Caetano, M., Almeida, P.R., Vale, C., Caçador, I., 2010. Accumulation and biological cycling of heavy metal in four salt marsh species, from Tagus estuary (Portugal). Environ. Pollut. 158, 1661-1668.

Duarte, B., Caçador, I., 2012. Particulate metal distribution in Tagus estuary (Portugal) during a flood episode. Mar. Pollut. Bull. 64, 2109-2116.

Dyer, F.M., Thomson, J., Croudace, I.W., Cox, R., Wadsworth, R.A., 2002. Records of change in salt marshes: a radiochronological study of three Westerschelde (SW Netherlands) marshes. Environ. Sci. Technol. 36, 854-861.

French, J.R., 2006. Tidal marsh sedimentation and resilience to environmental change: exploratory modelling of tidal, sea-level and sediment supply forcing in predominantly allochthonous systems. Mar. Geol. 235, $119-136$.

French, J.R., Burningham, H., 2003. Tidal marsh sedimentation versus sea-level rise: a southeast England estuarine perspective. In: Davis, R.A. (Ed.), Proceedings International Conference on Coastal Sediments 2003. World Scientific Publishing and East Meets West Productions, Corpus Christi, pp. 1-14.

French, J.R., 1993. Numerical-simulation of vertical marsh growth and adjustment to accelerated sea-level rise, North Norfolk, UK. Earth Surf. Process. Landforms 18 (1), 63-81.

Gates, D.M., 1993. Climate Change and its Biological Consequences. Sinauer Associates, Inc., USA.

Goodman, J.E., Wood, M.E., Gehrels, W.R., 2007. A 17-yr record of sediment accretion in the salt marshes of Main (USA). Mar. Geol. 242, 109-121.

Gornitz, V., 1991. Global coastal hazards from future sea level rise. Palaeogeogr. Palaeoclimatol. Palaeoecol. 89, 379-398.

Houghton, J., 1999. Global Warming: The Complete Briefing, Second edition. Cambridge University Press, UK, pp. 251.

Intergovernmental Panel on Climate Change (IPCC), 1990. Climate change. In: Houghton, J.T., Jenkins, G.J., Ephraumus, J.J. (Eds.), The IPCC Assessment. Cambridge University Press, UK http://www.ipcc.ch/pub/reports.htm

Intergovernmental Panel on Climate Change (IPCC), 1999. Aviation and the Global Atmosphere. A Special Report of Working Groups I and III of the Intergovernmental Panel on Climate Change. Summary for Policymakers. IPCC, Switzerland http://www.ipcc.ch/pub/reports.htm

Intergovernmental Panel on Climate Change (IPCC), 2007. Climate Change 2007: The Physical Science Basis. Contributions of Working Group I to the Fourth Assessment Report of the Intergovernmental Panel of Climate Change. Cambridge University Press, New York, NY, pp. 996.

Krone, R.B., 1987. A method for simulating historic marsh elevations. In: Krause, N.C. (Ed.), Coastal Sediments '87. American Society of Civil Engineers, New York, pp. 316-323.

Lijklema, L., 1980. Interaction of orthophosphate with iron III and aluminum hydroxides. Environ. Sci. Technol. 14, 537-541.

López, P., Llunch, X., Vidal, M., Morguí, J.A., 1996. Adsorption of phosphorus on sediments of the Balearic Islands Spain related to their composition. Estuarine Coastal Shelf Sci. 42, 185-196.

Lopez, P., Navarro, E., Marce, R., Ordoñez, J., Caputo, L., Armendol, J., 2006. Elemental ratios in sediments as indicators of ecological processes in Spanish reservoirs. Limnetica 25, 499-512.

Martins, M., Ferreira, J., Calvao, T., Figueiredo, H., 1984. Nutrientes no estuário do Tejo-comparação da situação em caudais médios e em cheia, com destaque para alterações na qualidade da água, Comunicação I. Simpósio Luso-Brasileiro de engenharia sanitária e ambiental.

Morris, J.T., Sundareshwar, P.V., Nietch, C.T., Kjerfve, B., Cahoon, D.R., 2002. Responses of coastal wetlands to rising sea level. Ecology 83, 2869-2877. 
Nyman, J.A., Carloss, M., DeLaune, R.D., Patrick Jr., W.H., 1994. Erosion rather than plant dieback as the mechanism of marsh loss in an estuarine marsh. Earth Surf. Process. Landforms 19, 69-84.

Nyman, J.A., DeLaune, R.D., Roberts, H.H., Patrick Jr., W.H., 1993. Relationship between vegetation and soil formation in a rapidly submerging coastal salt marsh. Mar. Ecol. Prog. Ser. 96, 269-279.

Oenema, O., DeLaune, R.D., 1988. Accretion rates in saltmarshes in the Eastern Scheldt, south-west Netherlands. Estuarine Coastal Shelf Sci. 26, 379-393.

Pont, D., et al., 2002. Response scenarios for the deltaic plain of the Rhone in the face of an acceleration in the rate of sea-level rise with special attention to Salicornia-type environments. Estuaries 25, 337-358.

Reed, D.J., 1990. The impact of sea-level rise on coastal salt marshes. Prog. Phys. Org. Chem. 14, 465-481.

Ritchie, J.C., McHenry, J.R., 1990a. Application of radioactive fallout ${ }^{137}$ Cs for measuring soil erosion and sediment accumulation rates and patterns: a review. J. Environ. Qual. 19, 215-233.

Ritchie, J.C., McHenry, J.R., 1990b. Application of radioactive fallout caesium-137 for measuring soil erosion and sediment accumulation rates and patterns: a review. J. Environ. Qual. 19, 215-233.

Roman, C.T., Peck, J.A., Allen, J.R., King J.W., Appleby, P.G., 1997. Accretion of a New England (U.S.A.) salt marsh in response to inlet migration, storms and sea-level rise. Estuarine Coastal Shelf Sci. 45, 717-727.

Rybczyk, J.M., Cahoon, D.R., 2002. Estimating the potential for submergence for two wetlands in the Mississippi River Delta. Estuaries 25, 985-998.

Rybczyk, J.M., Callaway, J.C., Day, J.W., 1998. A relative elevation model for a subsiding coastal forested wetland receiving wastewater effluent. Ecol. Model. 112, 23-44.

Salgueiro, N., Caçador, I., 2007. Short-term sedimentation in Tagus estuary, Portugal: influence of salt marsh plants. Hydrobiologia 587, 187-193.

Sarreta, A., Pillon, S., Molinaroli, E., Guerzoni, S., Fontolan, G., 2010. Sediment budget in the Lagoon of Venice, Italy. Continent. Shelf Res. 30, 934-949.
Silva, H., Dias, J., Caçador, I., 2009. The role of salt marsh vegetation in sedimentation processes. Hydrobiologia 621, 33-47.

Simas, T., Nunes, J.P., Ferreira, J.G., 2001. Effects of climate change on coastal salt marshes. Ecol. Model. 139, 1-15.

Stevenson, J.C., Ward, L.G., Kearney, M.S., 1986. Vertical accretion in marshes with varying rates of sea-level rise. In: Wolfe, D.A. (Ed.), Estuarine Variability. Academic press, Orlando, pp. 241-259.

Tardy, Y., Bustillo, V., Boeglin, J.L., 2004. Geochemistry applied to the watershed survey: hydrograph separation, erosion and soil dynamics: a case study: the basin of the Niger River, Africa. Appl. Geochem. 19, 469-518.

Temmerman, S., Govers, G., Meire, P., Wartel, S., 2003a. Modelling long-term tida marsh growth under changing tidal conditions and suspended sediment concentrations, Scheldt estuary, Belgium. Mar. Geol. 193, 151-169.

Titus, J.G., Narayanan, V.K., 1995. The Probability of Sea-level Rise. Environmental Protection Agency, USA http://users.erols.com/jtitus/Holding/NRJ.html

Turekian, K.K., Wedepohl, K.H., 1961. Distribution of the elements in some major units of the Earth's crust. Geol. Soc. Am. Bull. 72, 175-191.

Van Dijkeman, K.S., Bossinade, J.H., Bouwema, P., Glopper, R.J., 1990. Salt marshes in the Netherlands Wadden Sea: rising high-tide levels and accrettion enhancement. In: Expected Effects of Climatic Change on Marine Coastal Ecosystems. Kluwer Academic Publishers, The Netherlands, pp. 173-188.

Van Wijnen, H.J., Bakker, J.P., 2001. Long-term surface elevation change in salt marshes: a prediction of marsh response to future sea-level rise. Estuarine Coastal Shelf Sci. 52, 381-390.

Ward, L.G., Kearney, M.S., Stevenson, J.C., 1998. Variations in sedimentary environment and accretionary patterns in estuarine marshes undergoing rapid submergence, Chesapeake Bay. Mar. Geol. 151, 111-134.

Werne, J.P., Sageman, B.B., Lyons, T.W., Hollander, D.J., 2002. An integrated assessment of a "type euxinic" deposit: evidence from multiple controls on black shale deposition in the Middle Devonian Oatka Creek Formation. Am. J. Sci. 302 110-143.

Wood, M.E., Kelley, J.T., Belknap, D.F., 1989. Patterns of sedimentation in the tidal marshes of Maine. Estuaries 12, 237-246. 